\title{
Results \\ of \\ Dr. E. MJöberg's \\ Swedish Scientific Expeditions \\ to \\ Australia 1910-1913. \\ 26. \\ Cryptophagidae, Cucujidae, Malacodermidae, Melandryidae, Mordellidae, Rhipidophoridae and Oedemeridae.
}

By

ARTHUR M. LEA, F. E. S.

Communicated October 26th 1921 by Chr. Aurivillius and Y. SJöstent.

The specimens sent to me for examination principally belong to the Malacodermidae, and of these the most interesting are some minute members of the genus Heteromastix. A few species, represented by damaged or obscure single specimens, were returned not fully named.

Fam. Cryptophagidae.

Telmatophilus koebelei ВцACKн. - Bellenden-Ker.

\section{Fam. Cucujidae.}

Inopeplus dimidiatus WATERH. - Blackall Range, Cedar Creek, Glen Lamington.

Inopeplus olliffi $v$. d. PoLl. = Malanda 


\section{Fam. Malacodermidae.}

\section{Metriorrhynchus ramicornis sp. nov. - Fig. 1.}

o Black; prothorax, scutellum and elytra brick-red.

Head with rostrum rather long (more than half the length of prothorax). Antennae rather long, second joint minute, third to tenth of moderate length, but each with a long ramus, eleventh about twice the length of nonramose portion of tenth. Prothorax moderately transverse, conspicuously seven-areolate, apex obtusely produced in middle, sides gently dilated to near base, where they are slightly incurved, but hind angles slightly produced and acute. Elytra parallelsided; with regular double rows of transversely oblong punctures, the alternate interstices somewhat elevated. Length, $14 \mathrm{~mm}$.

Hab. - Queensland: Yarrabah (Dr. E. МлӧвеRG). Type in Stockholm Museum.

On the antennae the ramus itself is slightly longer than its supporting tenth joint, on the others it is about twice as long; the median areolet of the prothorax is narrow, and has a slight longitudinal medio-basal elevation. The entirely pale prothorax, scutellum, and elytra, with other parts black, long rostrum and ramose antennae readily distinguish from most species of the genus; in my table ${ }^{1}$ would be associated with $M$.nigripes, $M$. uniformis, and $M$.textilis, the two former have very different antennae in the male.

A female from Queensland (H. J. CARTER), and one from Cairns (E. Allen), evidently belong to the species, they differ from the type in having antennae shorter, and the third to tenth joints strongly serrated (subpectinated), with the abdomen not notched. They differ from the female of $M$. textilis (the only sex of that species at present known), by the different sides and base of prothorax, with the carinae less pronounced, but in particular by the strongly serrated antennae, even the third joint being strongly produced on one side of apex; on textilis that joint being hardly produced to one side.

${ }^{1}$ LEA, Trans. Ent. Soc. Lond., 1909, p. 51. 
ARTHUR M. LEA, CRYPTOPHAGIDAE, CUCUJIDAE ETC.

\section{Metriorrhynchus angustus sp. nov.}

¿ Sooty-black, prothorax and part. of base of elytra brick-red.

Head with rostrum very short or absent. Antennae moderately long and acutely serrated. Prothorax moderately transverse, conspicuously seven-areolate, apex gently rounded in middle; and almost as wide as base, sides angularly narrowed to middle, front angles rounded off, hind ones almost rectangular; apical areolets larger than usual, the median ones at apex slightly wider than the lateral ones. Elytra thin and parallel-sided; with regular, double rows of punctures, the alternate interstices moderately elevated. Length, $6 \mathrm{~mm}$.

Hab. - Queensland: Cedar Creek (Dr. E. MзöвеRg). Type (unique) in Stockholm Museum.

A curious narrow species; in my table would be placed with $M$. longicollis and $M$. costicollis, from the former it differs in being much smaller and narrower, the pale parts not flavous, and not abruptly and evenly terminated on the elytra, prothorax somewhat longer, base and apex of almost even width, and with different areolets; in general appearance it is fairly close to costicollis, and $M$. ruficollis, but the antennae are strongly serrated instead of flabellated. The pale portion of the elytra covers about the basal fourth on the costae, and somewhat less on the punctures, but the two rows on each side of the suture are dark throughout.

Metriorrhynchus lateralis REDT. - Two specimens (sexes) from Mount Tambourine, appear to belong to this species, but have the rostrum even longer than on the typical form, and the third joint of antennae longer and more parallelsided; similar specimens are before me from Brisbane and the Tweed River.

Metriorrhynchus irregularis WATERH. - In the original description of $M$. irregularis the prothorax was described as "rufo-flavo, medio nigro» and again »Thorax yellowish, black in the middle». The specimens I have previously identified as this species, have the black of the prothorax touching both base and apex; but a specimen taken by Dr. MJöBerG at Colosseum, and several from Howell (taken by Mr. J. F. StePhen), have the black touching neither base nor apex; 
but, as these structurally agree with the other, the difference is presumably only. varietal.

Metriorrhynchus longicornis MacL. - A female, from Cedar Creek, appears to belong to this species, but differs from the typical form in having the prosternum, mesosternum, trochanters, front and middle coxae pale, and rather more of the elytra pale (slightly more than one third). Typical specimens were taken at Atherton and Evelyne.

Metriorrhynchus elongatus MACL. - A female, from Atherton, possibly belongs to $M$. elongatus, but there are several undescribed species extremely close to it, and it is inadvisable to name any of them without kncwing botb sexes.

Metriorrhynchus simplicicornis Lea. - Three specimens, taken by Dr. MJöвerG at Atherton and Malanda, belong to this species (of which only the type was previously known). Others now before me are from Mount Tambourine (H. J. Carter, H. Hacker, and A. M. Lea), Caloundra, Mapleton, and Brisbane (H. HACKEK). On several specimens the costae connecting the median areolet with the sides are rather feeble, but on others quite conspicuous, so that the prothorax should be truly regarded as five-areolate; the elytral punctures are in single series on parts of the elytra, but towards the base and apex the series become more or less doubled, many of the punctures appear as $\mathrm{Y}$-s, transversely placed.

Metriorrhynchus rufipennis FAB. - Kuranda.

Metriorrhynchus rhipidius W. S. MACL. - Blackall Range, Brisbane, Glen Lamington.

Metriorrhynchus miniatus MACL. - Bellenden-Ker, Malanda, Yarrabah.

Metriorrhynchus nigripes MacL. - Colosseum.

Metriorrhynchus posticalis MACL. - Yarrabah.

Metriorrhynchus serraticornis MacL. - Colosseum.

Metriorrhynchus fallax WATERH. - Laura.

Metriorrhynchus irregularis WATERH. - Colosseum, Glen Lamington. 
ARTHUR M. LEA, CRYPTOPHAGIDAE, CUCUJIDAE ETC.

Metriorrhynchus atricornis Lea. - Atherton, BellendenKer, Herberton, Yarrabah.

Metriorrhynchus basalis Lea. - Atherton, Cedar Creek.

Metriorrhynchus batesi LEA. - Glen Lamington, Mount Tambourine.

Metriorrhynchus cryptolencus Lea. - Mount Tambourine.

Metriorrhynchus flavolimbatus LeA. -- Mount Tambourine.

Metriorrhynchus triareolatus LeA. - Fremantle, Perth.

Metriorrhynchus uniseriatus Lea. - Mount Tambourine.

Trichalus placidus sp. nov.

ơ Sooty-black; prothorax, scutellum, elytra (except apical fourth or fifth), coxae, trochanters and base of femora flavous.

Antennae rather long, third joint twice as long as the apical width, the others to tenth feebly decreasing in length and width, eleventh about half as long again as tenth. Prothorax slightly longer than the apical width, sides strongly elevated and somewhat sinuous, front angles obtuse, hind ones produced and acute. Elytra thin and parallel-sided, alternate interstices distinctly elevated, subsutural one trifurcate at basal fourth. Length ( $0^{7}$ \%), 7-9 $\mathrm{mm}$.

$q$ Differs in having antennae shorter and more feebly serrated, prothorax slightly wider, subapical segment of abdomen not notched, and legs somewhat shorter.

Hab. - Queensland: Malanda, Yarrabah, Bellenden-Ker (Dr. E. Muöberg), Cairns (E. Allen). Type in Stockholm Museum.

In my table ${ }^{1}$ would be placed with $T$. flavopictus (on account of the protborax not notched in front), from which it differs in being smaller, narrower, and median areolet of prothorax not darker than the others.

Trichalus basipennis sp. nov. - Fig. 2.

o Black; prothorax, scutellum, basal fourth of elytra, and front and middle coxae flavous.

${ }^{1}$ Loc. cit., p. 90. 
Antennae moderately long, third to tenth joints acutely serrated. Prothorax about as long as apical width, front angles rounded, hind ones produced and acute, sides evenly incurved to middle, central areolet about two-thirds the length of the segment, connected with apex by a costa; with rather dense punctures on apical third, and margining base and sides. Elytra thin and parallel-sided, subsutural costa trifurcate near base. Length, 6,75 $\mathrm{mm}$.

Hab. - Queensland: Cedar Creek, in April (Dr. E. MJöBerg). Type (unique) in Stockholm Museum.

In general appearance resembling a small female of $T$. semiatratus, but prothorax narrower and of somewhat different shape, and black of elytra more advanced towards the base, \&c; in my table would be associated with $T$. griffithi, which is a narrower species, with much less of elytra black. The pale portion of the elytra is slightly longer on the elevated parts than on the punctures.

Trichalus nubicollis FaIRM.? - Three specimens from Bellenden-Ker, Yarrabah and Colosseum, are extremely close to $T$. nubicollis, and I cannot satisfactorily distinguish them from specimens of that species.

Trichalus froggatti MACL. - Specimens were obtained at Atherton, Bellenden-Ker, Cedar Creek, and Malanda; several of the Atherton specimens have an infuscated blotch on the discal areolet (but not including its margining costae) and a space on each side of it at the base.

Trichalus semiatratus LEA. - Specimens were obtained at Cedar Creek, Malanda and Yarrabah. The female (hitherto unknown) differs from the male in having the antennae serrated and considerably shorter.

Trichalus angustulus MACL. - Cairns, Cedar Creek.

Trichalus ater MACL. - Atherton, Bellenden-Ker, Cedar Creek, Malanda, Yarrabah.

Trichalus atripennis MACL. - Cedar Creek.

Trichalus nubicollis FAIRM. - Bellenden-Ker, Malanda, Yarrabah.

Trichalus ampliatus WATERH. - Mount Tambourine. 
ARTHUR M. LEA, CRYPTOPHAGIDAE, CUCUJIDAE ETC. 7

Trichalus ampliatus var. auritus LeA. - Atherton, Cedar Creek.

Trichalus sulcatus Waterh. - Atherton, Herberton, Yarrabah, Bellenden-Ker.

Trichalus infaustus Lea. - Atherton.

Luciola flavicollis MACL. - Specimens were taken at Bellenden-Ker and Colosseum, a female from the latter place has the basal fifth of the elytra pale, and the pale lateral margins wider than usual; but I can find no structural differences between it and typical females.

Luciola humilis Orıv. - Atherton, Bellenden-Ker, Malanda.

Luciola platygaster Lea. - Bellenden-Ker, Herberton.

Atyphella lychnus OLL. - Mount Tambourine.

Atyphella olivieri Lea. - Atherton, Malanda.

Telephorus rubriceps MacL. - On the male of this species the black of the elytra is sometimes continued along the sides (but not actually on the margins), so that it looks like an elongated $\mathrm{U}$; it is very distinct from the males of all the allied species by the basal joint of its antennae; this is deep black, highly polished, and about twice as thick as in the female. Specimens were taken by Dr. MJöвERg at Bellenden-Ker, and others before me are from South Johnstone River and Innisfail, localities all fairly close to Cairns.

Telephorus pulchellus W. S. MACL. - Fremantle.

Telephorus froggatti MaCs. - Bellenden-Ker.

Telephorus mastersi MACL. - Atherton, Malanda, Bellenden-Ker, Colosseum.

Telephorus mossmani MacL. - Atherton, Cedar Creek, Malanda.

Telephorus imperialis REDT. - Mount Tambourine.

Telephorus nobilitatus ER. - Atherton, Cedar Creek, Herberton. 
Telephorus gracilipictus LEA. - Herberton.

Telephorus variiventris LeA. - Malanda.

Selenurus mjöbergi sp. nov. - Fig. 3.

$\delta$ Black and flavous. Clothed with very short pubescence, varying in colour with the derm.

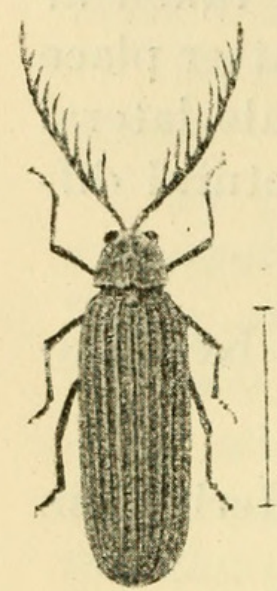

1

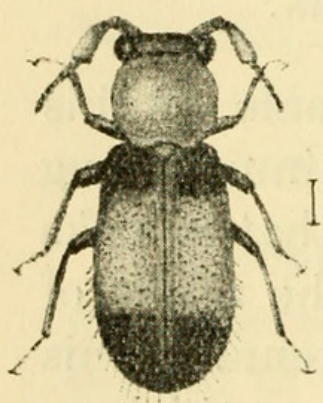

6
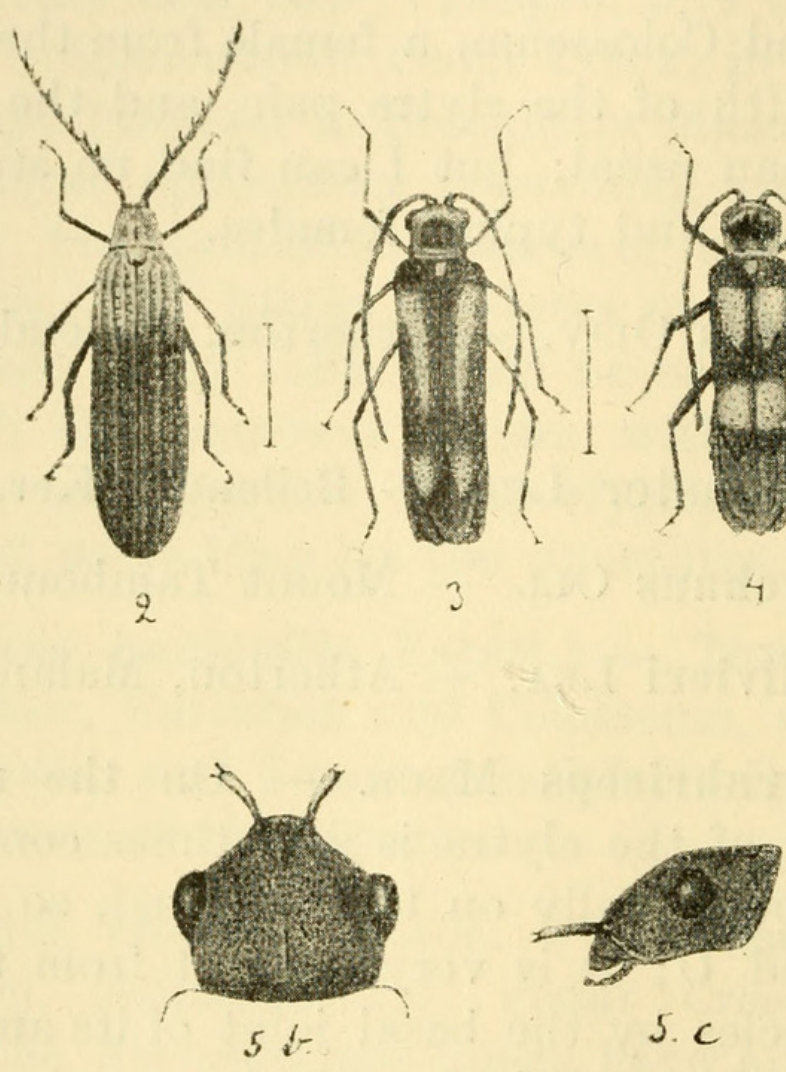

Fig. I Metriorrhynchus ramicornis n. sp.; 2 Trichalus basipennis n. sp.; 3 Selenurus mjöbergi n. sp.; 4 Selenurus apiciniger n. sp.; 5 a-c Laius ephippiatus n. sp.; 6 Laius tetrastictus n. sp.; 7 Carphurus insigniceps n. sp.

Head gently concave between eyes (which are large and prominent), strongly narrowed thence to base; with very minute punctures. Antennae long and thin, third joint about half the length of fourth. Prothorax longer than wide, disc uneven, sides and suture thickened, apex gently produced in middle; punctures very minute. Elytra long, thin, and gently narrowed posteriorly, much wider than protborax, with a feeble discal costa about half the length of each elytron; with dense and rather small rugose punctures. Subapical segment of abdomen semicircularly incised. Legs long and thin. Length ( $\delta$ 우), 7-9 $\mathrm{mm}$. 
o Differs in having the head smaller, eyes less prominent, more of the muzzle and under-surface dark, and subapical segment of abdomen not deeply incised.

Hab. - Queensland: Malanda (Dr. E. MJöвerg). Type in Stockholm Museum.

The flavous parts of the male are portions of three basal joints of antennae, prothorax (a large black discal blotch excepted), scutellum, an oblique vitta on each elytron (commencing near the shoulder and terminated near the apex), and their tips, most of stern, tips of most of the abdominal segments, coxae, femora (except knees), and base of tibiae. The species is allied to $S$. annulatus, but the prothoracie blotch is subbasal, instead of subapical, and the elytra have a black elongate triangle on the suture, isolating a pale vitta on each elytron. In S. flavoinclusus, which has the protborax immaculate, there is a black subtriangular space at the base of the elytra, but it is very short (much wider than long) whereas on the present species the sutural portion is wider than long, the pale vittae also extend to the sides near the shoulders, instead of being completely enclosed by black, as on that species.

Selenurus apiciniger sp. nov. - Fig. 4.

$\delta$ Black and flavous. Clothed with short and mostly ashen pubescence.

Head rather wide across eyes, strongly narrowed to base; with minute punctures. Antennae rather long and thin, third joint about half the length of fourth. Prothorax slightly transverse, surface uneven, margins thickened; punctures minute. Elytra thin and narrowed posteriorly, terminated considerably before apex of abdomen; with dense rugulose punctures. Subapical segment of aldomen semicircularly incised. Legs long and thin. Length ( $0^{7}+$ ), $5-7 \mathrm{~mm}$.

o Differs in having the head smaller, with less prominent eyes, less of muzzle pale, and in the abdomen.

Hab. - Queensland: Herberton, Cedar Creek (Dr. E. MJöberG), Mackay (R. E. Tcrner). Type male and cotype female in Stockholm Museum; type female, 1, 12208, in South Australian Museum.

The flavous parts of the male are much of the muzzle, prothorax (a large blackish blotch excepted), scutellum, a 
triangular vitta on each elytron (commencing near the base and ending about the middle), a fascia near apex, parts of sterna and tips of most of the abdominal segments; the antennae are obscurely flavous, with the eleventh joint and some of the median ones infuscated, parts of the legs are also obscurely pale. The blotch on the prothorax occupies about one-third of its surface, and has a projection towards each side, and two towards base. On one female the antennae have all the joints beyond the third infuscated, but on another they are as on the male. In my table ${ }^{1}$ would be referred to C C, but very different from $S$. tricolor and $S$. variegatus, the two species there noted. The elytral markings are close to those of S. luteopictus, but the subbasal ones are smaller, prothorax with discal blotch and antennae with some of the subapical joints pale; also more of the under-surface and legs are pale than on that species. The black tips to the elytra readily distinguish from $S$. mjöbergi.

Selenurus V-flavus Lea. - The type of this species is a female with the ninth joint of antennae paler than the others, but on many specimens now before me (including eight taken by Dr. MJöBERG), the ninth joint is as dark as the others; on several, however, the ninth, and on one the eighth and ninth are pale. The male differs from the female in being smaller, with the head wider across the eyes, more of the muzzle flavous, the antennae and legs longer, and the apical segment of abdomen with some curious appendages; on both sexes, however, the subapical segment is semicircularly emarginate at apex.

Hab. - Queensland: Lamington Flat and Mount Tambourine (Dr. E. MJöberG), Mount Tambourine (H. J. CarTer, H. Hacker and A. M. Lea); New South Wales: Dorrigo (W. HERON).

Selenurus luteopictus FaIrm. - Mount Tambourine.

Selenurus viridipennis MACL. - Cedar Creek.

Heteromastix insignicornis sp, nov. - Fig. 8 .

$\delta$ Black; head, prothorax, scutellum, basal joints of an-

1 Loc. cit., p. 126. 
tennae, front legs and parts of others flavous. Moderately pubescent.

Head gently convex, with rather small eyes. Antennae with first joint stout and moderately long, second short, third about as long as wide, fourth to eighth moderately transverse, ninth about as long as three preceding combined, and much wider, somewhas compressed, one side of apex truncated, the inner apex

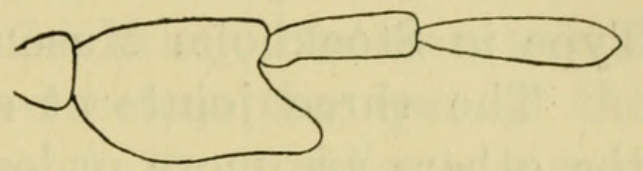

Fig. 8. Heteromastix insignicornis LEA. Four terminal joints of antennae. obtusely produced, tenth about as long as ninth but scarcely as long as eighth, eleventh slightly longer than tenth and near apex slightly wider. Prothorax about twice as wide as long, with a few submarginal punctures. Elytra parallel-sided to near apex; with crowded and rather small but sharply-defined punctures. Subapical segment of abdomen triangularly incised in middle. Basal joint of front tarsi lopsided. Length $3 \mathrm{~mm}$.

Hab. - Queensland: Evelyne (Dr. E. MJöвеRg). Type (unique) in Stockholm Museum.

The ninth joint of the antennae is inflated, but it differs from that of $H$. mcdonaldi, H. macleayi, and $H$. fusicornis in being produced at the inner apex, and with the two following joints much longer and thinner, the body is also narrower.

Heteromastix mirocerus sp. nov. - Fig. 9.

$\widehat{c}$ Black; apical half of head, prothorax, legs (hind femora infuscated in middle), and antennae (the median joints infuscated) flavous. Clothed with short ashen pubescence.

Head gently convex, with two feeble interocular impressions. Antennae moderately long, third joint subtriangular, twice the length and width of second, and slightly longer than first, fourth with a large triangular projection on one side, fifth with a strong pro-

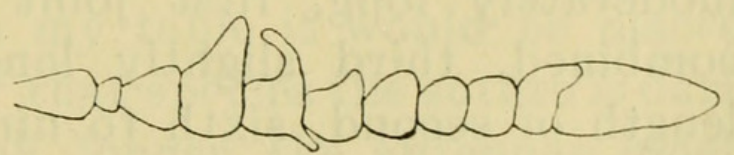

Fig. 9. Heteromastix mirocerus LEA. jection curved backwards on one side of apex, and a slight forward projection on the other, sixth slightly produced on one side of apex, and slightly larger than seventh, eighth and ninth simple, tenth and eleventh closely applied together and distorted. Prothorax about twice as wide as long, lateral 
margins somewhat dilated and thickened near apex. Elytra almost parallel-sided to near apex; with dense and small but rather sharply defined punctures. Legs rather long and thin. Length, 3,25-3,5 $\mathrm{mm}$.

Hab. - Queensland: Glen Lamington (Dr. E. MJöвеRG). Type in Stockholm Museum.

The three joints at each end of the antennae are pale, the others are more or less infuscated; the tenth and eleventh joints are so closely applied together that, as they are partly obscured by pubescence, it is difficult to see their true shapes, the eleventh, howerer, is somewhat dilated at the base, approaching the helmet-shape of that of $H$. gagaticeps and of other species; the fourth and fifth joints are the most remarkable ones, and readily distinguish the species from all other known ones.

Heteromastix diorycerus sp. nov. - Fig. 10.

$\delta$ Black; prothorax, scutellum, legs (tarsi more or less infuscated), three or four basal joints of antennae, and most of palpi flavous. With very short pubescence.
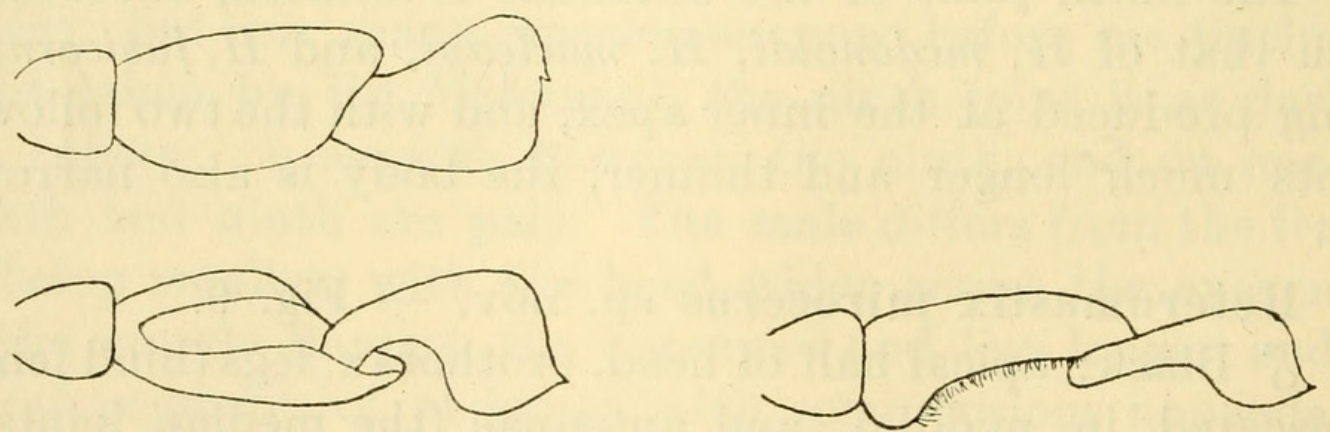

Fig. 10. Heteromastix diorycerus LEA. 3 terminal joints of antennae from different points of view.

Head with two faint interocular impressions. Antennae moderately long, first joint as long as second and third combined, third slightly longer than fourth, and twice the length of second, sixth to ninth feebly transverse, tenth and eleventh distorted. Prothorax akout twice as wide as long, sides and base conspicuously margined, the former slightly dilated to near apex, but not thickened. Elytra almost parallel-sided to near apex; with dense and small rugose punctures. Length ( $\tilde{\sigma}+), 4-4,5 \mathrm{~mm}$.

o Differs in having the head somewhat smaller, antennae shorter, thinner, with simple joints, and abdomen not notched. 
Hab. - Queensland: Cedar Creek, in March (Dr. E. MjöвerG). Type in Stockholm Museum.

The tenth joint of the antennae of the male is about as long as the seventh-ninth combined, and distinctly longer than the eleventh, lopsided, convex on one side and with a large pubescent excavation on the other, the eleventh is thin at the base, which is inserted before the apex of the tenth, and suddenly inflated beyond its middle to apex, which has two small spines (seldom visible together from the same points). As with other species having the tenth and eleventh joints distorted, they alter in appearance with the point of view. The tenth joint is very large also in $\mathrm{H}$. crassicornis, but of very different shape.

\section{Heteromastix glaber sp. nov.}

$\delta^{\lambda}$ Black; scutellum, basal two-fifths of elytra, sterna (except sides of prosternum), four basal segments of abdomen, legs (parts of tarsi infuscated), two basal joints of antennae, and part of the third, and parts of palpi flavous. Uppersurface glabrous and highly polished, lower-surface finely pubescent.

Head feebly impressed between eyes. Antennae rather long and thin, third joint slightly stouter than the following ones. Prothorax fully twice as wide as long, margined throughout, sides slightly wider near apex than at base. Elytra long, slightly dilated beyond middle; with dense and sharply defined, but not very large punctures, in places feebly confluent. Length, $3,25 \mathrm{~mm}$.

Hab. - Queensland: Malanda (Dr. E. MJöвerG). Type (unique), in Stockholm Museum.

A very distinct species; the black part of the elytra is evenly rounded in front so as to be nearer the base at the suture than at the sides. In my table it would be placed with $H$. dolicocephalus, but on that species the suture is dark throughout, the head is much longer, the antennae much shorter, \&c.

\section{Heteromastix castigatus sp. nov.}

$\delta$ Black, prothorax flavous. With short, ashen pubescence.

Head with two minute interocular impressions. Antennae long and thin, eleventh joint twice the length of eighth. Prothorax not twice as wide as long, margined throughout, sides 
gently rounded and nowhere thickened; with submarginal punctures. Elytra long, thin and parallel-sided; with dense and sharply defined punctures of moderate size, becoming smaller on tips. Length, 2,25 $\mathrm{mm}$.

Hab. - Queensland: Mount Tambourine, in October (Dr. E. MJöвеRG). Type (unique), in Stockholm Museum.

In size and general appearance close to $H$. pusillior, but prothorax with sides not dilated or thickened in front, ninth joint of antennae the length of tenth, but slightly thicker, longer than eighth and much shorter than eleventh; the three apical joints are about as long as the five preceding ones, on pusillior they are scarcely as long as the four preceding ones. The ninth joint is certainly thicker than the adjacent ones, and a small part of its surface is shining, but the difference is so slight, that the species could hardly be regarded as allied to $H$. fusicornis, $H$. mcdonaldi and similar species; so in my table ${ }^{1}$ would be placed with $H$. victoriensis, from which it is at once distinguished by its much smaller size. A variety of pusillus occurs on Mount Tambourine that is as small as this species, but it has the typically dilated and thickened prothoracic margins of that species. At first glance the appendages appear to be entirely dark, but the two basal joints of antennae and parts of the front legs are obscurely paler than the adjacent parts.

Heteromastix luridicollis MacL. - Two females, from Mount Tambourine, with only the apical fifth of elytra black.

Heteromastix flavifrons LEA. - A specimen, from Mount Tambourine, agrees perfectly with the type of $H$. flavifrons, except that the apical joint of antennae is less noticeably incurved to one side.

Heteromastix nigriceps Lea. - Two specimens, from Mount Tambourine, probably belong to this species, but differ from the type in having the prothoracic margins rather thicker near apex (but not suddenly and strongly increased or subdentate, as in $H$. denticollis), and the elytra slightly dilated posteriorly.

Heteromastix castor LEA. - Glen Lamington.

1 Loc. cit., p. 131. 
Heteromastix decipiens Lea. - Mount Tambourine.

Heteromastix laticollis Lea. - Bellenden-Ker, Cedar Creek, Christmas Creek, Malanda.

\section{Laius ephippiatus sp. nov. - Fig. 5 a-c.}

o Opaque; black, with a vague bluish tinge, head, undersurface of first joint of antennae, and part of abdomen, of a dingy red; elytra dull purplish-blue, a flavous fascia at basal third, commencing rather narrowly at the suture, and dilated to the sides. With very minute, ashen pubescence, and some long, straggling, black hairs.

Head with punctures so dense, minute, and rugose, as to appear shagreened; with a feeble median line near base. Antennae simple, apparent second joint almost as long as two following combined. Prothorax rather strongly transverse, apex about twice the width of base; finely shagreened. Elytra narrow at base, sides conspicuously dilated to near apex, and then widely rounded; densely granulate-punctate throughout. Legs long and thin, front femora and tarsi simple. Length, $4 \mathrm{~mm}$.

Hab. - Queensland: Cedar Creek, in March (Dr. E. MJöвerg). Type (unique), in Stockholm Museum.

Although the type is a female I have not besitated to describe it; the entirely opaque upper-surface, with elytra greatly narrowed to base (the width there being distinctly less than that of the apex of prothorax), being without parallel in the genus; the elytral punctures are just as crowded on the blue parts as on the saddle-like fascia; the hind tibiae are unusually long, somewhat curved, and with narrow ridges. It appears to be apterous.

Laius tetrastictus sp. nov. - Fig. 6.

o Flavous; elytra with four blue or purple spots, metasternum, part of hind femora and apical half, or more, of antennae, infuscated or black. With long, scattered, pale brown hairs.

Head with two feeble depressions in front; punctures small and in places fairly dense. Antennae with first joint rather long and stout, the apparent second longer and stouter than first, obtusely produced at outer apex, lower-surface convex, upper-surface irregularly concave, five apical joints 
not serrated. Prothorax moderately transverse, much wider at apex than base, a wide and rather deep depression near base; punctures dense on parts of sides, sparse elsewhere. Elytra almost parallel-sided to near apex, sides and suture tbickened; with dense but sharply defined punctures, except on parts of the basal spots, and on most of the apical spots. Front femora deeply notched in middle of front; second joint of front tarsi lopsided, and with a black outer comb. Length (oㅇ), $2,5-3 \mathrm{~mm}$.

$q$ Differs in having the head smaller, more convex and with less prominent eyes, antennae with first joint thinner, the apparent second much smaller, simple, and about as long as the two following combined, front femora and second joint of front tarsi simple.

Hab. - North-Western Australia: Kimberley district (Dr. E. MJöвеrg). Type, and many other specimens, in Stockholm Museum.

Of the elytral spots two are basal and are prevented from contact only by the thickened suture, the others are longer, oval, and touch or almost touch the apex, but not the suture, they are usually more purplish than the basal ones. On some specimens the hind legs are almost entirely dark, on others they are entirely pale; on many of them there is a dark spot adjacent to each eye. Of the minute species, having pale protborax and four-spotted elytra, the basal joints of antennae are alone sufficient to distinguish from $L$. purpureiceps and $L$. acervatus, which have also apical spots of different shape and with conspicuous punctures on them; $L$. eyrensis, $L$. egemus, $L$. carus, and $L$. sinus are smaller, and with the head dark, $L$. stenotarsus has dark and wider prothorax, $L$. concaviceps has very different head, and elytral spots longitudinally conjoined, and L. xallidus is smaller, wider, and with different elytral punctures.

Laius bellulus GUER. - Perth.

Laius carus Lea. - Kimberley, Noonkanbah.

Hypattalus mirabilis LEA. - Evelyne.

Carphurus insigniceps sp. nov. - Fig. 7.

$\delta$ Flavous; six apical joints of antennae, a large blotch on elytra, metasternum, middle and hind coxae, and femora 
black or blackish. With sparse pale pubescence, and long, dark hairs.

Head large, densely punctate and opaque, a wide and rather deep transverse impression behind eyes, shallow depressions and three short longitudinal ridges between them, base rather strongly convex. Antennae rather long, third to tenth joints serrated, eleventh no longer than tenth. Prothorax slightly longer than the greatest width (near apex), base decidedly narrower than apex, a wide depression near base, a shallow fovea on each side near apex; sides with dense punctures, sparse elsewhere. Elytra more than twice the length of prothorax, sides rather suddenly dilated near base; with dense and sharply defined punctures. Basal joint of front tarsi with a narrow, black, inner comb, from base to apex. Length, $6 \mathrm{~mm}$.

Hab. - North-Western Australia: Kimberley district, in January (Dr. E. MJöвеRG). Type (unique) in Stockholm Museum.

The head is very curious, its longitudinal elevations from some directions appear to be connected at the base by a feeble ridge, so as to resemble an $\mathrm{E}$ on its side; the dark blotch on the elytra commences on the suture at the basal third, and gradually dilates rearwards, but at the apex is suddenly dilated so as to cover the entire tips. The antennae are not 》very strongly» serrated, but so regarding them the species in my table ${ }^{1}$ might be associated with $C$. longipes, from which it is distinguished by the curious head, and differently coloured elytra; regarding the antennae as »feebly" serrated, it would be associated with $C$. atricapillis, from which it differs in many respects.

Carphurus telephoroides FAIRM. - A male from Mount Tambourine apparently belongs to this species, but differs from the description, and from a specimen in my collection, in having the head immaculate, its elytra are brightly coppery, the comb on each front tarsus extends almost the full length of the basal joint.

Carphurus elegans LEA. - One specimen, of several taken at Cedar Creek, has the pale portion at base of elytra rather larger than on the types.

1 Loc. cit., p. 188.

Arkiv för zoologi. Band 14. N:o 11. 
Carphurus longus Lea. - Numerous specimens, of Form 4, of this species, all females, were taken at Atherton, Cedar Creek, Herberton, and Malanda, two of them have parts of the metasternum infuscated. One specimen, of Form 5, was taken at Bellenden-Ker.

Carphurus vigilans LeA. - A male, from Cedar Creek, belonging to this species, has the basal fourth of elytra flavous, and the legs entirely flavous, except for the comb on each front tarsus. Another specimen was taken at Bellenden-Ker.

Carphurus armipennis FAIRM. - Atherton.

Carphurus cristatifrons FAIRM. - Atherton, Cedar Creek.

Balanophorus mastersi MACL. - Bellenden-Ker, Colosseum, Glen Lamington, Herberton, Rockhampton.

Balanophorus scapulatus FAIRM. - Mount Tambourine.

Neocarphurus impunctatus LEA. - A specimen, from Mount Tambourine, structurally agrees with the type, but its prothorax is deep black, except at the base, and four of the terminal joints of the antennae are infuscated.

\section{Helcogaster caviceps sp. nov.}

$\delta$ Flavous; scutellum, apical third of elytra, most of abdomen, coxae and femora (except knees) black; two basal joints of antennae and most of the third and fourth pale, the others black or blackish. With sparse, dark hairs.

Head wide, with a large, deep, median elevation, sides between excavation and eyes sloping upwards, punctate and opaque. Antennae moderately long, most of the joints slightly longer than wide. Prothorax about as long as the greatest width (near apex), surface gently undulating, but with a large obtuse tubercle in each front angle. Elytra slightly longer than wide; scarcely visibly punctate. Basal joint of front tarsi with a small black comb. Length, 3,25 $\mathrm{mm}$.

Hab. - Queensland: Malanda (Dr. E. MJöвerg). Type (unique), in Stockbolm Museum.

The conspicuous tubercle on each front angle of the prothorax, with the curious head, render the male of this species a very distinct one; its colours, however, are much 
as in $H$. rhyticephalus, and several other species. The uppersurface of the abdomen is black, with the tip and sides of each segment reddish, but a greater amount of the undersurface is black. On the type the base of the head has a deep transverse impression, but this would probably be concealed on most specimens.

Helcogaster geniculatus sp. nov.

$\delta$ Black; four basal joints of antennae, knees, and front tibiae and tarsi more or less reddish. With some inconspicuous hairs on sides.

Head wide, a small deep impression between eyes, marking the centre of a very shallow depression, behind this a narrow elevation to base, and in front of it a feeble elevation, gently concave along its middle to apex; with dense punctures. Antennae moderately long. Prothorax near apex distinctly wider than long; a fairly wide subbasal depression, closed at each end. Elytra not very long, dilated from near base; with numerous minute, rugulose punctures. Basal joint of front tarsi lopsided, with a black inner comb. Length, $2 \mathrm{~mm}$.

Hab. - Queensland: Mount Tambourine (Dr. E. MJöBerG). Type (unique), in Stockholm Museum.

From some directions the head appears to have a fairly large interocular depression, with an acute tubercle overhanging the middle of its base. In some lights the parts of the head adjacent to the eyes appear to be obscurely diluted with red. Regarding the species as belonging to a a of my table $^{1}$ it would be associated with $H$. ater, which has a large portion of head pale, and the excavations and antennae different.

Helcogaster punctipennis LeA. - Five females, from Malanda, Herberton and Cedar Creek, possibly belong to this species, but differ from the typical form in having the elytral punctures less sharply defined, although distinct; each has a small fascicle of black hairs, at the middle of the apex of the antepenultimate segment of abdomen.

Helcogaster bacchanalis LEA. - Mount Tambourine.

Dasytes fuscipennis Hope. - Alice River, Cape York Peninsula, Herberton, Mount Tambourine.

1 Loc. cit, p. 215. 


\section{Fam. Melandryidae.}

Seraptia immatura sp. nov.

Pale flavous, head slightly infuscated. Clothed with very short, whitish pubescence.

Head gently convex, with dense and minute punctures. Eyes large, close together in front, rather less deeply notched than usual in genus. Antennae almost twice as long as head is wide. Prothorax about thrice as wide as long, punctures much as on head. Elytra with outlines continuous with those of prothorax, parallel-sided to near apex, which does not quite cover the tip of abdomen; with dense and minute punctures. Spurs to hind tibiae unequal. Length, $1,5 \mathrm{~mm}$.

Hab. - North Western Australia: Kimberley district (Dr. E. MJöвERG). Type, and three other specimens, in Stockholm Museum.

The smallest species of its genus as yet known from Australia. There is a depression on each side of the prothorax, and a narrow median line, but the depressions vary in size, and the median line in deptb, apparently owing to irregular contraction in drying.

Fam. Mordellidae.

Mordella calopasa LEA? - A specimen from Mount Tambourine, $9 \mathrm{~mm}$ in length, possibly represents a variety of this species, it differs from the typical and other varietal forms, in having the beautiful golden pubescence of the elytra uniformly continued to beyond the middle, and with a large round spot on each near the apex, the adjacent surface with a few golden hairs scattered about; the middle legs are entirely dark, and the basal joints of antennae obscurely reddish.

Mordella elongatula MACL. -- Bellenden-Ker.

Mordella notabilis MacL. - Bellenden-Ker.

Mordella leucosticta Germ. - Colosseum.

Mordella graphiptera Chамт. - Mount Tambourine.

Mordella vitticollis LeA. - Bellenden-Ker.

Mordellistena austrina Снамг. - Mount Tambourine. 
Fam. Rhipidophoridae.

Emenadia tricolor Gerst. - South Perth.

Emenadia rufofasciata Lea. - Colosseum.

Pelecotomoides conicollis CAST. - Cedar Creek.

Pelecotomoides marmoratus MacL. - Herberton.

Pelecotomoides nigrolateralis LEA. - Atherton.

Pelecotomoides subparallelus Lea. - Tolga.

Fam. Oedemeridae.

Techmessa bifoveicollis LEa. - Two specimens, from Mount Tambourine, may belong to this species (both are mouldy and one is badly broken), but they differ from the type in having the elytra flavous, except at the basal fifth and apical third.

Pseudolycus haemopterus Guer., var. puberulus B Lack b. - Mount Tambourine.

Pseudolycus wallacei Lea. - Mount Tambourine.

Morpholycus apicalis MACL., var. I. - Brisbane, Glen Lamington.

Nacerdes melanura Linn. - Brisbane.

Dohrnia bifoveicollis Lea. - Mount Tambourine. 


\section{$2 \mathrm{BHL}$ Biodiversity Heritage Library}

Lea, A. M. 1922. "Results of Dr E. Mjöberg's Swedish Scientific Expeditions to Australia 1910-1913. 26. Cryptophagidae, Cucujidae, Malacodermidae, Melandryidae, Mordellidae, Rhipidophoridae and Oedemeridae." Arkiv för zoologi 14, 1-21. https://doi.org/10.5962/bhl.part.7725.

View This Item Online: https://www.biodiversitylibrary.org/item/30164

DOI: https://doi.org/10.5962/bhl.part.7725

Permalink: https://www.biodiversitylibrary.org/partpdf/7725

\section{Holding Institution}

MBLWHOI Library

\section{Sponsored by}

MBLWHOI Library

\section{Copyright \& Reuse}

Copyright Status: NOT_IN_COPYRIGHT

This document was created from content at the Biodiversity Heritage Library, the world's largest open access digital library for biodiversity literature and archives. Visit BHL at https://www.biodiversitylibrary.org. 